This is a so-called personal version (author's manuscript as accepted for publishing after the review process but prior to final layout and copyediting) of the article.

Vaara, E., Tienari, J. and Säntti, R. The international match: Metaphors as vehicles of social identity building in cross-border mergers. Human Relations, 2003, 56(4), 419-451.

Researchers are kindly asked to use the official publication in references.

\title{
The international match: Metaphors as vehicles of social identity-building in cross-border mergers
}

\author{
Eero Vaara
}

Janne Tienari

Risto Säntti 


\section{ABSTRACT}

This article focuses on cultural identity-building in the cross-border merger context. To provide an alternative to the dominant essentialist analyses of cultures and cultural differences, cultural identitybuilding is conceptualized as a metaphoric process. The focus is on two processes inherent in the cross-border merger context: construction of images of Us and Them and construction of images of a Common Future. Based on an analysis of a special metaphor exercise carried out in a recent Finnish-Swedish merger, the article illustrates how the metaphoric perspective reveals specific cognitive, emotional and political aspects of cultural identity-building that easily remain 'hidden' in the case of more traditional approaches.

KEYWORDS: culture, identity, merger, metaphor 


\section{INTRODUCTION}

Mergers and acquisitions are examples of dramatic events that trigger various kinds of organizational culture- and identity-building processes. Hence, the growing stream of research focusing on 'cultural issues' in this context is not surprising. These have gained specific attention in cross-border cases in which the cultural differences are arguably rooted in different institutional and sociocultural settings, thus creating long-term barriers to social integration (e.g. Gertsen et al., 1998; Olie, 1994). People have also examined acculturation (Elsass \& Veiga, 1994; Nahavandi \& Malekzadeh, 1988) and comparative (Very et al., 1997) processes in these contexts as keys to social integration and motivation. With relatively few exceptions, these studies have, however, shared an 'essentialist' conception of culture (Gertsen et al., 1998; Vaara, 1999). By objectifying cultural characteristics, studies have not been able to 'dig deep' into cultural conceptions in specific settings as part of individual and collective identity-building processes. This has tended to result in a lack of understanding of the social construction of cultures and the related identification processes.

We maintain that cultural conceptions play a major role in post-merger organizational integration, but that the construction of these conceptions is a complex social identitybuilding process that is still poorly understood. Drawing from social identity and selfcategorization theories (Ashforth \& Mael, 1989; Hogg \& Terry, 2000; Tajfel \& Turner, 1979; Turner, 1985), our point of departure is that the core of this process is the construction of prototypical and sterotypical images. Rather than simplistic or stable constructions, these images are produced in a process of interpretations that not only deals with the actors' firsthand experiences, but also involves reconstruction of historical stereotypes, myths and legends from different social domains.

The problem is that such presentations are very difficult to 'capture' using traditional methods. One of the reasons is that traditional methods of analysis do not appear to be equipped to bring to the surface the multiple and even contradictory meanings associated with cultural categories. To provide a new approach, we propose that the cultural identification processes involved in merger situations could be seen as metaphoric processes. More specifically, this article has two objectives: (i) to outline a theoretically grounded perspective to examine cultural identity-building as a metaphoric process, and (ii) to examine and elaborate on the key aspects of these processes in the context of a recent merger between the Finnish Merita Bank and the Swedish Nordbanken. 
We first provide a brief overview of research on metaphors, which forms the basis of our interactionist understanding of metaphors. Next, we outline our perspective on cultural identity-building as a metaphoric process. We specifically distinguish two intertwined processes inherent in the crossborder merger context. On the one hand, merging involves a need to construct one's own identity in relation to the other party, that is, images of Us and Them. On the other hand, identity-building in the merger setting involves constructions of common identity in the new organization, that is, images of the Common Future. We then turn to our empirical setting and focus on a metaphor-building exercise involving the top managers of the Finnish-Swedish MeritaNordbanken organization. In this analysis, we in particular point to the strength of national cultural imagery and single out specific stereotypes characterizing the Finnish-Swedish relationship. As our main point, we then illustrate how a metaphoric perspective allows us to reveal specific cognitive, emotional and political aspects of cultural identitybuilding that easily remain 'hidden' in the case of more traditional approaches.

\section{METAPHORS AND ORGANIZATIONAL CHANGE}

Metaphors and other tropes have intrigued philosophers, linguists, literary critics, psychologists, anthropologists and sociologists for a long time (Black, 1962; Fernandez, 1991; Lakoff \& Johnson, 1980; Miller, 1982; Ortony, 1975, 1979; Sacks, 1978).1 Ever since Aristotle, people have tended to distinguish logical and metaphoric texts and treat metaphors predominantly as 'ornaments'. This distinction has, however, been questioned as people have found that metaphors are important linguistic vehicles through which they can effectively communicate without long lists of elaborations, coin meaning that is difficult or impossible to express otherwise, and thereby vividly transfer holistic experiences (e.g. Ortony, 1975). People have also traditionally seen metaphors as implicit comparisons. This view has, however, been found to be inadequate. In particular, the proponents of an interactionist view (Black, 1962; Richards, 1936) have emphasized that it is not the comparison as such but the creation of new meaning by the interaction of two different domains of meaning that is crucial in metaphors.

For sociological and cultural analysis, the work by Lakoff and Johnson (1980) has been especially influential. By adopting the interactionist view, they argued that metaphors are pervasive not just in languge, but in social thought and action as well. In fact, a strong 
version of their thesis is that the most fundamental values in a culture will be coherent with the metaphorical structure of the most fundamental concepts of the culture. They also emphasized the 'generative' powers of metaphors as means to create new meaning and understanding, thus connecting cognition and action. This kind of view also links metaphors and 'power' in a way that is much more encompassing than the traditional rhetoric view would imply (Booth, 1978; Bosman, 1987). Others have later criticized the views of Lakoff and Johnson for an overemphasis of the constitutive role of metaphors at the cost of neglecting other tropes such as synecdoche, metonymy and irony. For example, Quinn (1991) has argued that instead of creating new culture, metaphors tend rather to reproduce existing cultural ideas.

Organization scholars have become increasingly interested in metaphors (Cazal \& Inns, 1998; Deetz, 1986; Gherardi, 2000; Grant \& Oswick, 1996; Morgan, 1986, 1993; Oswick \& Grant, 1996; Oswick et al., 2002; Putnam et al., 1996). Metaphors have, in particular, inspired methodological thought (Manning, 1979), epistemological reflection around theorybuilding (Oswick et al., 2002; Tsoukas, 1991), work on the ontology or 'images' of organizations (Morgan, 1986), and empirical analysis (Gherardi, 2000; Schön, 1979; Yanow, 1992). Cazal and Inns (1998) summarize why many researchers have found metaphors appealing for empirical analysis. First, metaphors give insights into hidden, barely conscious cognitions and feelings, which the participants have about belonging to a particular group. Second, metaphors are useful as they enable researchers to see 'beyond their existing frameworks and models' (Miles \& Huberman, 1994). Third, metaphors convey meaning to readers of a text in a particularly concise way. Miles and Huberman (1994) call them 'datareducing' devices, as they are able to convey many connotations and meanings to the reader.

Of the empirical studies on organizational change, Schön (1979) has already focused attention on the 'generative' role of metaphors in the context of technological innovation and urban housing. By singling out 'frame awareness,' 'frame conflict' and 'frame restructuring,' he promoted the view that by constructing a new way of looking at 'problems' one can reconcile previously conflicting frames and metaphors. This could take place precisely by finding new metaphoric ways of framing the problematic situation (frame restructuring). Although the simplistic features of this kind of analysis have later been criticized (Miller, 1985), the power of metaphors to break free from previous conceptions has inspired many organization and management scholars (e.g. Marshak, 1993). In the context of Israeli 
community centers, Yanow (1992) examined the linkage of metaphors, figures of thought and action. In particular, she brought out the role of organizational metaphors as part of organizational action and the normative implications of specific metaphors. Sackman (1989) examined the metaphors in a conglomerate transformation processes. She showed how the use of multiple metaphors allowed a wide range of organizational action and specifically argued that 'adaptive' metaphors (such as 'gardening') are often more helpful than 'targeted' (such as 'engineering') metaphors.

Oswick and Montgomery (1999) pointed out in their analysis of the 'car' and 'animal' metaphors of an organization that metaphors can be useful devices to gain understanding of 'hidden' ideas and values, but that metaphors may also mislead and obscure. In her study of a transforming Italian municipality, Gherardi (2000), in turn, showed how seeing metaphors as dreamwork collapses the traditional divide between seeing metaphors as either heuristic (manifestations of something learnt) or generative (means to create new understanding). In her case, she also illustrated how different metaphors may exist simultaneously without any apparent awareness of their dissonance. In this case, the Italian community could, for example, be simultaneously viewed as family and pyramid. Whereas most of the studies of metaphors on organizational change have not explicitly taken up questions of power, Wilson's (1992) study of the adoption of new computer systems points to the inherent discriminatory power of metaphors. She argues that metaphors effectively create gendered 'in' and 'out' groups. The language used - such as military and religious metaphors - both reproduces relations of power and marks out the 'rules' as how change is to be achieved.

\section{CULTURAL IDENTITY-BUILDING AS A METAPHORIC PROCESS}

What does it then mean to view cultural identity-building as a metaphoric process? As pointed out in studies on social identity, social identity-building involves self-categorization in which one places oneself within a category (Tajfel, 1982; Tajfel \& Turner, 1979; Turner, 1985). Building such categories also means (usually subconscious) creation of ingroups and outgroups; understood in terms of Self and Other or Us versus Them.

The metaphoric approach emphasizes that this categorization is a process where meanings from different social domains are connected to each other to create or recreate cultural understanding in the form of prototypes and stereotypes. The key point here is that 
this process is based on situationspecific interaction in which the emerging meanings and subsequent categories are highly dependent on the available (often subconscious) experiences and their linguistic representations in different social domains. Through metaphoric expressions, the often hidden conceptions (including prejudices) come to the surface (e.g. Alvesson, 1993; Schön, 1979). At the same time, creation of new metaphors can substantially recreate the social identities and the relevant categories. The metaphoric, although it does not need to be restrained to articulated language, nevertheless, stresses the role and limits of our linguistic resources in these processes. In good and bad, available narratives, stories, myths and legends thus shape our cultural categorizations.

A key 'problem' with the metaphoric approach is that the meanings created are literally situation-specific creations. This means acceptance of inherent ambiguity in cultural conceptions, especially if we are examining the conceptions of a large group of people forming organizations. In fact, the metaphoric creations of particular subjects and the associations given even for the same metaphoric expressions are also idiosyncratic, and can ultimately be understood only in relation to a personal code of meaning. Yet this does not undermine the power of specific metaphors in cultural identity-building. On the one hand, the social domains and the respective discourses that form the basis of metaphors are not infinite in number in specific organizational settings. On the contrary, we all know how often we fall prey to pre-given official corporate rhetoric or banal ethnic prejudices. On the other hand, as pointed out earlier (e.g. Gherardi, 2000), different metaphors can co-exist perfectly well in organizations and even be sustained by the same persons.

Dramatic organizational changes such as mergers create a need to individually and collectively make sense of the new situation; for example, what is the new organization, what it means to be part of that organization, and what are the changes concerning one's own membership and role within that organization. Such sense-making is essentially identityconstruction (e.g. Weick, 1995), and the identity-building processes are thus crucial in terms of understanding how the people involved respond to the planned and anticipated 'changes'.

In brief, this identity-building is likely to involve two specifically important processes: (i) construction of images of Us and Them, and (ii) construction of images of the Common Future. First, as in any encounters, the actors involved are likely to (re)construct their identities in relation to the other. This means focusing on specific observable, known or imagined cultural differences. In a cross-border merger setting, one can analytically talk 
about a 'double' acculturation or identity-building process because that involves not only organization-specific but also national identities. However, the metaphoric view emphasizes that the specific metaphors created can often successfully compress or integrate various aspects of identities or multiple identities in a single image. Consequently, instead of singling out specific unit, organizational and national identities, the people involved in mergers may often come up with unique compact metaphors. Second, mergers also involve a process of constructing an image of the joint future identity of the postmerger organization. As studies on mergers and acquisitions have indicated (Vaara, 1999), this is a crucial process in determining the future integration, social cohesion and ultimately effective functioning of the post-merger organization.

What are then the imageries that are likely to provide bases for these two metaphoric identification processes? In brief, especially the previous organizational identities, national identities and images of the merger or acquisition are likely to be important elements. First, as to the previous organizational identities, they are built through histories, narratives and other forms of shared experience. Contrary to what is often believed in more traditional organizational analysis, these identities need not be enduring but can be relatively fluid and unstable, precisely because of the multiple images available (Gioia et al., 2000). The nature of relevant images is dependent on the situation. For example, whether an organization appears to be 'mechanistic,' 'bureucratic,' 'organic,' 'dynamic,' 'thinking,' 'open,' 'clan-like' or whatever is relative to the other organization as the merger partner.

Second, national identities play a key role in international settings. However, the construction of national cultural conceptions and identities has been relatively unexplored in the organizational context dominated by the essentialist conception of cultural differences (see, however, Breakwell \& Lyons, 1996). National protypes and stereotypes are particularly strong categorizations that often tend to be reproduced in international encounters. Again, it is, however, important to emphasize that the construction of identity and difference is a relationship-specific contrastive process. Although such comparisons may take different forms in different circumstances, it is interesting to note that nations often tend to be seen as 'cultural competitors,' reflected in the central role of warfare and sports in nationalism (e.g. Löfgren, 1993). It is also very common to place oneself in the 'golden mean' in comparisons and generally produce an overly postive view of one's competencies (e.g. Löfgren, 1993). 
Third, in addition to the specific organizational and national imageries, the images of the merger or acquisition in question play a key role in these processes. Unfortunately, only a few studies have examined the metaphors around mergers and acquisitions and they have focused exclusively on hostile takeovers. Hirsch and Andrews (1983) emphasized the prominent role of warfare images in hostile takeovers. Hirsch (1986) presented and described ideologies, genres and metaphors found in media texts concerning hostile takeovers. Hirsch's analysis revealed how particular ideas linked with warfare, games and religion were legitimized and institutionalized through language. Schneider and Dunbar (1992) examined the meanings ascribed to hostile takeovers from a psychoanalytic perspective. Schneider and Dunbar proposed a classification according to which takeovers can be interpreted as 'takeovers for growth,' 'takeovers for control,' 'takeovers for dominance' or 'takeovers for synergy'. They emphasized that the analysis revealed emotional responses of fears and desires related to developmental concerns such as dependency, control, mastery and intimacy. In friendlier circumstances, one could assume that, for example, images of marriages would prevail.

In conclusion, one can thus understand metaphors as means to access the constructed cultural realities of organizational members. They can help us both understand the construction of the existing cultural representations and identities of the members of an organization and serve as means to construct new identities for membership in the organization. These social identity processes manifested by metaphors involve complex cognitive, emotional and political processes. To be able to explore these elements, we now turn to our empirical case.

\section{THE METAPHOR EXERCISE IN MERITANORDBANKEN}

Nordbanken has its origin in PKbanken (Post och Kreditbanken), founded in 1974 through a merger between Sveriges Kreditbank and Postbanken. As the name indicates, the bank was connected to the postal system of the Swedish state. In 1990, PKbanken acquired what was then called Nordbanken, which also became the name for the new merged bank. Nordbanken was the bank most badly hit by the Swedish banking crisis in the late 1980s and early 1990s, and its rescue required a great deal of capital from the Swedish state. The newly formed Nordbanken was a distinctly private customer-oriented bank. 
The Finnish Merita Bank is also a product of earlier mergers and acquisitions. The latest took place in February 1995, when the two largest and most influential commercial banks in Finland, the Union Bank of Finland (UBF) and Kansallis Banking Group joined forces. The new name Merita Bank was launched some three months later. It is important to note that, whereas UBF's image was bilingual (i.e. including Swedish-speaking Finns), Kansallis had a distinctively Finnish image. In media texts on the merger of the banks, employees of the former UBF were sometimes referred to as 'Serbs,' whereas former Kansallis employees were referred to as 'Croats'.

The decision to merge Merita and Nordbanken was announced in October 1997. At the time, it was the largest merger to take place between Finnish and Swedish organizations, and one of the few cross-border mergers in the banking industry. It was launched as a union of equals. The voting rights in the new bank were distributed 50-50 between Swedes and Finns. Swedes, however, owned 60 percent of the share capital. The new bank continued to operate under the name Nordbanken in Sweden and Merita in Finland.

Already at the outset, the corporate management of the new bank was concerned about the challenge of 'cultural differences' that had received a great deal of attention in the media in the context of previous Finnish-Swedish mergers and acquisitions. More accurately, it was the Finnish side of the new management, who had first-hand experience of managing cultural differences, that was the active party. As one of the actions to work on these differences, specific Finnish persons then proposed that the new bank should carry out a 'cultural seminar' series similar to that held in Merita in the context of the domestic merger between Kansallis and UBF.

A group led by one of the authors of this article was appointed to be in charge of a 'cultural seminar' series. The official objective of the corporate culture seminar process was to present people with opportunities to create cross-national understanding through discussion, and thereby come up with suggestions for the senior management concerning practical measures for developing the corporate culture of MeritaNordbanken. The people participating in the seminars were also to define practical, personal measures in order to enhance cultural understanding in their own organizational units.

There was also a hidden agenda in the seminar series, promoted by specific Finnish managers, to make visible the problems experienced in the Finnish side of the organization. 
One of the key problems was that some weeks after the merger announcement in October 1997, the senior management in MeritaNordbanken announced that the 'official corporate language' in the new bank would be Swedish. This was an extremely controversial decision from the perspective of the Finns, creating both practical communication problems and symbolizing Swedish dominance.

A total of approximately 330 top managers and experts participated in 20 corporate culture seminars held in MeritaNordbanken in 1999 and 2000. The corporate culture seminars were held in Swedish since Swedish had been chosen as the official corporate language. This did not cause immediate problems for the organizers because they (including one of the authors) spoke fluent Swedish. However, the selection of Finnish participants, although in principle based on units and tasks, was affected by the individuals' (anticipated) skills in the Swedish language.

In preparation for the seminars, the participants were asked to fulfil specific tasks on their own: outline their own personal observations of the merger partner and list possible opportunities and threats involved in the 'cultural situation' at hand. As background material, they also received a brief description of what kinds of cultural differences one might look at in international contexts, influenced by the work of Laine-Sveiby (1991) and Lewis (1996). The organizers of the cultural seminars were in general satisfied with the 'results' of the cultural seminars after the first rounds. However, they wanted to 'dig deeper' and engage people in 'less traditional' and 'more innovative' reflection around the cultural differences. Consequently, for the participants in the nine seminars held in the autumn of 1999, preseminar preparation included an additional task. They were presented with the following exercise:

Write down metaphors that in your view best describe

Merita

Nordbanken

MeritaNordbanken (in the future)

(A metaphor is a figurative comparison, for example, an organization as a factory, a garden, a storm, a home, a battlefield, a spider's web, etc.) 
A total of 282 metaphors were produced by the 175 persons attending these cultural seminars.2 Although the metaphors can be seen as fairly authentic productions, it is apparent that the setting and the circumstances of the exercise greatly influenced their specific nature. For example, the metaphors tend to cohere very well with the ideas presented in the preexercise background material. One can also assume that the task itself - structured as it was forced one to first focus on differences and then look at the similarities to the extent that it remains questionable as to how similar or different the participants actually view the organizations and themselves in more 'natural' circumstances.

A summary of the individually produced metaphors (lists of the metaphors) was sent to the participants along with other material (including readings on Finnish-Swedish cultural differences) before the seminar sessions started. The metaphor material was intended to serve as a means for both individual reflections around cultural issues and as background material for the discussions in the cultural seminars. Although there was no specific planned session on the metaphors in the program of the cultural seminars, they were frequently discussed explicitly.

Some of the metaphors also 'took off'. For example, the former CEO of Merita redeveloped, together with the participant group, an interesting metaphor during the last culture seminar in January 2000. The participants suggested the metaphor of 'two orphans without parents becoming a family of at least four children' for the new organization. The final version of this was a 'family with grown-up children'. The interpretation was that the grown-up children were the country organizations (Finland and Sweden), which should be seen as responsible units within the familial group context.

Retrospectively, it is also easy to see how many people developed 'Nordic' metaphors for the new organization. In particular, the corporate culture and identity development has later drawn from this imagery. After a subsequent merger with a Danish partner in 2000 and an acquisition of a Norwegian bank, the name of the group became Nordea. In 2000, the corporate management also started an extensive corporate image campaign focusing on 'Nordic ideas'.

More generally, it is very difficult to evaluate the effects of the cultural seminar series in general or the metaphor exercise in particular. Apparently, this facilitated exercise increased the cultural 'awareness' of the participants and also contributed to increasing self- 
understanding. At the same time, as will become clear in the following sections, it also tended to reproduce existing stereotypes.

\section{METHODOLOGY: THE REINTERPRETATION OF THE METAPHORIC CONSTRUCTION}

During the course of the cultural seminars and the following official and unofficial feedback sessions and discussions, the metaphors could be interpreted and reinterpreted in a variety of ways, at best creating new insights into the cultural identity development challenges and suggesting new ways of building mutual value base, trust and commitment. For the purposes of this article, we have, however, reinterpreted the metaphor material to gain more understanding of the metaphoric identity-building processes in such cross-border settings.

Analyzing this metaphor material is not unproblematic (e.g. Cazal \& Inns, 1998). A key question is the position, cultural background and frame of reference of the interpreter. In this case, all of us three authors are Finnish and are thereby likely to provide a 'Finnish reading' of the metaphors. This can be seen as a 'methodological problem,' but we maintain that all readings and reinterpretations of such material inadvertedly reflect a specific frame with particular sociocultural and ideological linkages. Furthermore, the idea of an 'unbiased' reading is clearly not the objective here. It is also important to note that we all have Finnish as our mother tongue but can understand and communicate in Swedish very well, meaning that the interpretation of the Swedish metaphors as such provided no immediate problems.

Another key question is whether the analysis of the metaphor material can proceed from a 'surface' to a 'deeper' level of understanding. Although this is a debated issue (e.g. Alvesson, 1993; Cazal \& Inns, 1998; Miller, 1985; Schön, 1979), we maintain that attempts to reach a 'deeper' level of understanding at least require specific and detailed contextual knowledge. In our case, key material was the detailed fieldnotes taken by one of the authors during the cultural seminars. His position in the bank also provided us access to all kinds of informal and formal documents, as well as possibilities to interview the managers involved in the metaphor exercises. It should also be noted that the other authors have studied the restructuring of these particular organizations and could thus draw on specific media and interview materials when reinterpreting the metaphor material.

Our inductive analysis proceeded in steps that resemble the stages of metaphor analysis described by Yanow (2000), although we have gone back and forth in this analysis. 
First, as a preliminary stage, we categorized the metaphors as shown in Table 1 (a revised categorization) to gain an understanding of the overall imageries and social domains in question.

These categories were thus not constructed a priori but emerged from the analysis. The imagery of the metaphors is very interesting as it shows how the contemporary business deal invoked all kinds of images that at first glance appear surprising. Although all the categories are interesting as such, the 'war and battle' and 'sports and game' categories are specifically noteworthy in a cross-border setting because of the central role of warfare and sports in national identity-building (e.g. Löfgren, 1993).

At the second stage, we then tried to decipher the specific meanings of particular metaphors. In particular, we linked the metaphors with three cultural frames: previous organizational identity, national identity and the specific merger setting. During this interpretation, we were initially surprised by the overwhelming linkages to national stereotypes, and therefore decided to concentrate on this rather unexplored area in organizational research. In this process, we eventually focused on 'active metaphors' (those apparently used in one way or another in the organizations) and 'revealing metaphors' (those seen as most revealing in terms of their linkages to 'hidden' cultural meanings).

At the third stage, we engaged in a detailed analysis of similarities, differences and common ground of the specific vehicles and topics. For example, a self-description of Nordbanken as a 'Phoenix' is likely to refer to the 'recreation' of the bank, through domestic mergers, after the serious banking crisis in Sweden. Similarly, viewing Nordbanken as a 'post office' is likely to be a reference to the historical origins of the bank as part of the Swedish postal system. A self-description of Merita as a 'battlefield' is likely to refer to the recent merger between UBF and Kansallis.

At the fourth stage, we then identified particularly 'strong' images, categorizations, prototypes and stereotypes that characterized the metaphoric material. Through them, we were able to single out such features in the construction of the metaphors that help us to understand the specifics of the two interrelated cultural identity-building processes: construction of difference and construction of a common future identity. These findings are discussed in the following sections. 
Table I Metaphors and social domains (some abbreviated)

\begin{tabular}{|c|c|c|c|c|c|c|}
\hline & $\begin{array}{l}\text { Nordbanken on } \\
\text { Nordbanken }\end{array}$ & $\begin{array}{l}\text { Nordbanken on } \\
\text { Merito }\end{array}$ & $\begin{array}{l}\text { Nordbanken on } \\
\text { MeritaNordbanken }\end{array}$ & $\begin{array}{l}\text { Merito on } \\
\text { Nordbanken }\end{array}$ & $\begin{array}{l}\text { Merito on } \\
\text { Merito }\end{array}$ & $\begin{array}{l}\text { Mertito on Merita- } \\
\text { Nordbanken }\end{array}$ \\
\hline Family and people & $\begin{array}{l}\text { - feudal soclety } \\
\text { - Inhabitant of the countryside } \\
\text { - male } \\
\text { - 'Svensson' (2) }\end{array}$ & $\begin{array}{l}\text { - clan } \\
\text { - doorman of the class } \\
\text { - home } \\
\text { - hunter } \\
\text { - junlor } \\
\text { - soclety in soclety } \\
\text { - teenager who wants everything }\end{array}$ & $\begin{array}{l}\cdot \text { familly, with two chlldren } \\
\text { - house } \\
\text { - young graduate }\end{array}$ & $\begin{array}{l}\text { - conservative co-worker } \\
\text { - father } \\
\text { - female farmer } \\
\text { - home } \\
\text { - kindergarten for adults } \\
\text { - little big brother that monitors } \\
\text { - monastery } \\
\text { - nelghbor }(2) \\
\text { - people's home (2) } \\
\text { - post office (2) } \\
\text { - university student }\end{array}$ & $\begin{array}{l}\text { - blg chlld } \\
\text { - child (2) } \\
\text { family } \\
\text { - home (2) } \\
\text { - male, middle-aged engineer } \\
\text { - university student }\end{array}$ & $\begin{array}{l}\text { - assoclation } \\
\text { - family celebration } \\
\text { - future clerical worker } \\
\text { - home } \\
\text { - marriage of female farmer and } \\
\text { male engineer } \\
\text { - mother } \\
\text { - new famlly } \\
\text { - professor }\end{array}$ \\
\hline War and battle & $\begin{array}{l}\text { - amount of guerilla force } \\
\text { - Infantry/staff battalion }\end{array}$ & $\begin{array}{l}\text { - barracks - a sergeant-major } \\
\text { shouting orders and conscripts } \\
\text { running } \\
\text { - Great Wall of China } \\
\text { - regiment } \\
\text { - tank battallon }\end{array}$ & $\begin{array}{l}\cdot \text { army } \\
\cdot \text { battlefield now, ellte force in the } \\
\text { future } \\
\cdot \text { professional army }\end{array}$ & $\begin{array}{l}\text { - headquarters } \\
\text { - parade ground }\end{array}$ & $\begin{array}{l}\text { - Asterlx's Gaullsh village } \\
\text { - battleground (2) } \\
\text { - castle } \\
\text { - Don Quixote } \\
\text { - dynamic trallblazer } \\
\text { - fortres } \\
\text { - naval pllot } \\
\text { - soldler }\end{array}$ & - SWAT team? \\
\hline Sports and game & $\begin{array}{l}\text { - game where NB players try to } \\
\text { make MNB methods as similar } \\
\text { as possible to those of the 'old } \\
\text { NB' } \\
\text { - Ice hockey team back again in } \\
\text { the top league } \\
\text { - plece of a puzzle } \\
\text { - several teams } \\
\text { - team player (2) } \\
\text { - track-and-field athlete running } \\
5.000 \mathrm{~m}\end{array}$ & $\begin{array}{l}\text { - football team } \\
\text { - game where MB players try to } \\
\text { avold a change of behavior } \\
\text { - puzzle } \\
\text { sprinter that starts fast and is used } \\
\text { to quick decislons and fast turns } \\
\text { - well-functioning team }\end{array}$ & $\begin{array}{l}\text { - athlete running the } 800 \text { meters } \\
\text { - chessboard } \\
\text { - decathlon champlon, Ice hockey } \\
\text { team } \\
\text { - football goal (gate to future } \\
\text { markets) } \\
\text { - real winner team } \\
\text { - star player scoring goals } \\
\text { - trampoline } \\
\text { - two teams joln forces to be more } \\
\text { competitive }\end{array}$ & $\begin{array}{l}\text { - game } \\
\text { - playing a game where one listens to } \\
\text { the other with the manners of a } \\
\text { master } \\
\text { - survival game (2) }\end{array}$ & $\begin{array}{l}\text { - computer game } \\
\text { - game (Is It played with full force } \\
\text { and openly?) } \\
\text { - home base (2) } \\
\text { - Individual athlete } \\
\text { - McLaren } \\
\text { - rowing competition in Sulkava }\end{array}$ & $\begin{array}{l}\text { - baseball team } \\
\text { - International match } \\
\text { - efficlent professional team } \\
\text { - football team } \\
\text { - game (with common tactics, } \\
\text { different Implementation) } \\
\text { - game with two boards } \\
\text { - Ice hockey team In Ist division } \\
\text { - national competition } \\
\text { - llgsaw puzzle } \\
\text { - quarterback/playmaker }\end{array}$ \\
\hline Bullding, vehicle and machine & $\begin{array}{l}\text { - contraption } \\
\text { - effective and energetic sewing } \\
\text { machines } \\
\text { - factory } \\
\text { - Lada (car) } \\
\text { - ocean-going vessel } \\
\text { - saloon } \\
\text { - ship trying to reach harbor } \\
\text { - station wagon (Volvo) } \\
\text { - summer cottage by the sea } \\
\text { - tanker } \\
\text { - walting room }\end{array}$ & $\begin{array}{l}\text { - blg tanker } \\
\text { - bulldozer } \\
\text { - eastern European street klosk } \\
\text { - factory } \\
\text { - motor blke - powerful, speedy } \\
\text { and dangerous } \\
\text { - pyramld } \\
\text { - shlp heading for harbor } \\
\text { - truck } \\
\text { - Volkswagen (Beetle) }\end{array}$ & $\begin{array}{l}\text { - bridge } \\
\text { - factory } \\
\text { - keel } \\
\text { - lelsure house } \\
\text { - Mercedes Benz } \\
\text { - Nordlc department store } \\
\text { - Nordic house } \\
\text { - Nordlc Viking ship } \\
\text { - power plant } \\
\text { - rocket } \\
\text { - steamboat } \\
\text { - tanker } \\
\text { - two jolnt factorles } \\
\text { - two lelsure houses }\end{array}$ & $\begin{array}{l}\text { - boat lost at sea } \\
\text { - guest house } \\
\text { - lelsure house by the sea } \\
\text { - lighthouse } \\
\text { - luxury crulser } \\
\text {. pyramid } \\
\text { - schooner } \\
\text { ship with old crew } \\
\text { - two big houses with a connection } \\
\text { at a high level } \\
\text { - Volvo Amazon } \\
\text { - walting room } \\
\text { - windmill }\end{array}$ & $\begin{array}{l}\text { - aeroplane with the auto pllot on } \\
\text { - flat (Interior design made, } \\
\text { furnishing missing) } \\
\text { - kite } \\
\text { - mangle } \\
\text { - tanker in the Baltic Sea } \\
\text { - two big houses with a } \\
\text { connectlon on a high level } \\
\text { - wooden cottage made of old } \\
\text { valuable wood }\end{array}$ & $\begin{array}{l}\text { - house made of stone } \\
\text { - house with open doors } \\
\text { - house with a touch of eastern } \\
\text { exotique and western } \\
\text { prosperity } \\
\text { - ship seeking new ports } \\
\text { - Volvo estate, automatic (car) }\end{array}$ \\
\hline
\end{tabular}


Table I Continued

\begin{tabular}{|c|c|c|c|c|c|c|}
\hline & $\begin{array}{l}\text { Nordbanken on } \\
\text { Nordbanken }\end{array}$ & $\begin{array}{l}\text { Nordbanken on } \\
\text { Merita }\end{array}$ & $\begin{array}{l}\text { Nordbanken on } \\
\text { MeritaNordbanken }\end{array}$ & $\begin{array}{l}\text { Merita on } \\
\text { Nordbanken }\end{array}$ & $\begin{array}{l}\text { Mertta on } \\
\text { Mertta }\end{array}$ & $\begin{array}{l}\text { Mertta on Merito- } \\
\text { Nordbonken }\end{array}$ \\
\hline Nature and animal & $\begin{array}{l}\text { - beehlve } \\
\text { : dinosaur } \\
\text { : garden from the 1950s } \\
\text { - phoenlx bird } \\
\text { - tiger with bad self-esteem }\end{array}$ & $\begin{array}{l}\text { - ant hill (2) } \\
\text { - Finnish hllon } \\
\text { - glacler } \\
\text { - mountain (3) } \\
\text { - splder's web } \\
\text { - summer meadow } \\
\text { - tger with tall ralsed high } \\
\text { - well-bullt tlger } \\
\text { - wolf } \\
\text { - woods }\end{array}$ & $\begin{array}{l}\cdot \text { eagle } \\
\text { : fog } \\
\text { : garden } \\
\text { : greenhouse } \\
\text { : gulp } \\
\text { : heart/muscle } \\
\text { : panther } \\
\text { : star } \\
\text { : tiger } \\
\text { - tree } \\
\text { - wave }\end{array}$ & $\begin{array}{l}\text { - ameba } \\
\text { - ant soclety } \\
\text { - antllope } \\
\text { : archipelago } \\
\text { - calm water } \\
\text { - cornflower } \\
\text { - deciduous forest } \\
\text { : glant panda } \\
\text { - hornet's nest } \\
\text { - millk cow } \\
\text { - mother goose }\end{array}$ & $\begin{array}{l}\text { : ant hlll (4) } \\
\text { : apple tree } \\
\text { : brown bear } \\
\text { : confferous forest } \\
\text { : elephant } \\
\text { : garden } \\
\text { - llon } \\
\text { - splder's web }\end{array}$ & $\begin{array}{l}\text { - ant hill } \\
\text { - dandellon } \\
\text { - eagle with two heads } \\
\text { : elephant } \\
\text { : garden } \\
\text { - horses } \\
\text { - new meadow of flowers } \\
\text { - polar bear sea } \\
\text { - sea glimmering in sun } \\
\text { - splder web }\end{array}$ \\
\hline Other & $\begin{array}{l}\text { - buffet board } \\
\text { - chewing gum } \\
\text { - fast shop } \\
\text { - fresh breath } \\
\text { - Island kingdom with missing } \\
\text { communication } \\
\text { - labyrinth } \\
\text { - mosalc } \\
\text { - organization structure } \\
\text { - patchwork quilt } \\
\text { - special place of my childhood }\end{array}$ & $\begin{array}{l}\text { - blg farm } \\
\text { - colossus (2) } \\
\text { - glant (3) } \\
\text { - Islands with chlefs } \\
\text { - spots on a map }\end{array}$ & $\begin{array}{l}\text { - conqueror (In crusade over the } \\
\text { Nordic and Baltic states) } \\
\text { - effective website } \\
\text { - fishing net } \\
\text { - great power period in peace time } \\
\text { - Microsoft (company) } \\
\text { - phantom } \\
\text { - plicture in a museum (Mona Lisa) } \\
\text { - university } \\
\text { - wallet }\end{array}$ & $\begin{array}{l}\text { - clvll service department } \\
\text { - cocktall party } \\
\text { - curlosity } \\
\text { - kitchen with many cooks } \\
\text { - telephone }\end{array}$ & $\begin{array}{l}\text { - first class restaurant turning } \\
\text { Into a fast food joint } \\
\text { - glant } \\
\text { - melting pot } \\
\text { - mlxed frutt soup } \\
\text { - out of boller to flowering } \\
\text { - publild transport service } \\
\text { - puding } \\
\text { - trawler's net } \\
\text { - unformed chunk } \\
\text { - unorganized hassle }\end{array}$ & $\begin{array}{l}\text { - Arlanda (Stockholm alrport) } \\
\text { : bureaucratic enterprise } \\
\text { - challenge } \\
\text { - Finnish-Swedish chaln of stores } \\
\text { - fishnet } \\
\text { : hurly-burly } \\
\text { : Jungle of corporate cultures } \\
\text { - La Scala team of Millan } \\
\text { - lump soup } \\
\text { - network } \\
\text { - office } \\
\text { - perpetual motion machine } \\
\text { - tower of Babel } \\
\text { trall crew }\end{array}$ \\
\hline
\end{tabular}




\section{CONSTRUCTION OF IMAGES OF US AND}

Constructing one's cultural identity in relation to others involves contextspecific prototypes amd stereotypes. When seen as a metaphoric process, it is possible to point to the rich (usually subconscious) imagery around the selfcategorizations. To exemplify, we take up three specific themes in cultural comparisons: conception of 'collectivism,' conception of 'action,' and conception of 'modernity'. We focus on these themes because they received a great deal of attention in the post-merger organization and because they were also highlighted (or at times even produced) in the discussions around the cultural seminars. Our intention is not to claim that these are the only interesting themes or that these images are not uncontroversial. On the contrary, we want to emphasize that when dealing with large numbers of people and metaphors (as is usually the case in identity-building in organizations), the possibilities for interpretation and reinterpretation are numerous.

\section{Collectivism}

'Collectivism' as well as 'individualism' are often taken up as issues when making sense of cultural differences. The metaphor material seems to point to relatively widely held conceptions of the 'participative' nature of Swedish organizations, in contrast to which Finnish organizations appear to be based more on 'individualism' and be 'authoritarian' in nature. The archetypal image of Swedish management style is participative; the manager is one of a group or a collective (Ekwall \& Karlsson, 1999; Laine- Sveiby, 1991; Zander, 1999). For example, Zander (1999) puts forth egalitarianism, empowering, cooperation and teamwork to be distinctively characteristic of management in contemporary Sweden. Several references to this direction could be detected in Nordbanken managers' (re)construction of Us:

Ice hockey team back again in the top league...

Several teams.

The references to team sports are hardly coincidental. In fact, during the last decades the Swedes - a relatively small nation - have succeeded extremely well in ice hockey and football championships. Especially in the Swedish case, with a rather long historical distance to wars, sports represents a particularly important social arena for national identity-building (see Löfgren, 1993).3 Interestingly, even when describing Nordbanken as an individual sportsman/woman, the account still switched to refer to a collective: 


\section{Team player.}

I see us as a track-and-field athlete running the 5000 meters, where we set the tactics before the race and preferably stick to them without sudden changes in tempo.

In this context, these self-descriptions appeared to 'work particularly well' because they could also refer to the recent (successful) restructuring of Nordbanken (e.g. 'back in the top league'). Metaphors such as 'team player' also seemed to hint at the readiness of Nordbanken organization to work with the new partner, reflecting a widely held conception that the Swedes had in this merger on average a more positive attitude towards cooperation than the Finns.

The Merita people seemed to often associate Nordbanken and the Swedes with 'participative' organization and management styles. The following metaphors constructed by Merita managers on Nordbanken are clear manifestations of this image:

People's home.

Kindergarten for adults.

Kitchen with many cooks.

The first of the metaphors above - 'the people's home' - is likely to refer to the Swedish 'model society' and 'welfare state' often associated with the Social Democrat rule. Apart from being an example for the Finnish society, this Swedish model has also been criticized by the Finns for overly egalitarian decision-making procedures and hypocrisy (e.g. Laine-Sveiby, 1991). The other two metaphors can be interpreted in the same way.

In Finnish-Swedish settings, Finns are often depicted as 'individualists' (e.g. LaineSveiby, 1991). Many of the metaphors, like 'individual athlete,' appear to construct such an image, although such descriptions can also be interpreted as images of an organization where everyone shares and is committed to the same objectives. In contrast to Swedes, metaphors of war and battle were used more frequently in the self-descriptions of the Finns. This is understandable when taking into consideration the recent national history of the Finns involving two wars against the Soviet Union. Interestingly, the metaphors often focused on the individual not the collective fighting the war or battle. Consider the following metaphors of Us by Merita managers: 
Soldier.

Naval pilot.

Dynamic trailblazer.

Don Quixote.

In particular the 'Miracle' of the Winter War (1939-1940), in which the Finns succeeded in repelling the mighty Red Army, has become an important part of Finnish nationalism (Apo, 1998). According to legend, the Soviets had quantity, the Finns quality. The apparent efficiency of the Finnish army was based on mobility, initiative and quick decisions down the chain of command. It has been pointed out that in the Finnish army 'every individual was fighting his own war'. These experiences of the war are arguably reflected in archetypal Finnish management style emphasizing individual responsibility and personal competence (e.g. Aaltonen, 1997).

It is also interesting to note that the self-descriptions of the Merita people referred to a specific kind of collective defensiveness:

Castle.

Fortress.

These descriptions seem to hint at an 'underdog' position expressed by many Finns (in specific interviews) in this merger.

The metaphors by Nordbanken people seemed to portray Merita and the Finns in ways that make a sharp contrast to their self-descriptions reflecting 'participation,' 'egalitarianism' and 'consensus'. Rather than reflecting the heroism of the self-descriptions of the Finns, these pointed explicitly or implicitly to the authoritarian Finnish management style:

Barracks - a sergeant-major shouting orders and conscripts running.

The descriptions of the Swedes also tended to point to specifically strong bonds on the Finnish side, as shown in the following metaphors reflecting some kind of 'exotic' collectivism: 
Clan.

Finnish lion.

$\underline{\text { Action }}$

Conceptions of 'action' are central to descriptions of contemporary organizations. The metaphor material arguably reveals images of 'order,' 'planning' and 'consensus' as characteristics of Swedes and Swedish organizations (e.g. Laine-Sveiby, 1987; Zander, 1999). In contrast, 'action orientation' and 'quick decision-making' are attributed to the Finns (e.g. Laine-Sveiby, 1991; Laurila, 1999).

In particular, the metaphors of Us by Nordbanken managers reflect a picture of an organization in which careful planning and order prevail (see also the athlete metaphor above):

Effective and energetic sewing machines.

Patchwork quilt consisting of several banks, and one that is beginning to get most of the patches in the right place.

Organization structure.

The two last metaphors also specifically refer to the succesful reconstruction of Nordbanken where 'all the pieces' have finally been put in their right places. With a self-critical tone, several metaphors by the Nordbanken people seem to paint the picture of a slightly oldfashioned and out-of-date organization (this may reflect Nordbanken's past as a part of the Swedish postal system):

Garden from the 1950s.

Tanker: a big, clumsy and formless bank which takes time to turn.

Summer cottage in a forest by a lake.

Merita people, in turn, seemed to pay more attention to the 'lack of action' in Nordbanken. Perhaps a contention that 'Swedes haven't seen real action for ages' - in contrast to the Finnish nation - is part of the meaning of the following metaphors: 4 
Parade ground.

Civil service department.

Metaphors such as 'cocktail party' in particular seem to reflect a commonly held Finnish view that the Swedes tend to discuss issues to the extent that it annoys the Finns. As expressed by many Finns in various contexts, it is also often very difficult to know when lengthy discussions have led into a 'consensus' and a 'decision' to form the basis for consequent action (e.g. Laine- Sveiby, 1991). These behavioral characteristics were among the most important topics taken up in the cultural seminars and overall frequently discussed issues on the Finnish side of the post-merger organization.

The animal-related metaphors of Nordbanken by Merita managers include images such as 'giant panda,' 'milk cow' or 'mother goose'. With the exception of 'hornet's nest,' these can be interpreted as 'harmless' and 'soft,' referring to the conservative nature of the Nordbanken organization.

In turn, the Merita managers were often eager to portray themselves as'action-oriented' and 'effective' decision makers. The military metaphors reviewed earlier are good examples. However, there were also more critical self-descriptions implying a lack of organization:

Unorganized hassle.

Ant hill. ${ }^{5}$

Metaphors constructed by Nordbanken managers on Merita reflect and construct an image of quick - and sometimes restless and poorly planned -decision making:

Sprinter starting fast and used to quick decisions and fast turns.

Motor bike - powerful, speedy and dangerous.

Hunter.

Teenager who wants everything, making demands in a way that doesn't always have a match in reality, can be self-assertive and at the same time uncertain, likes praise and can be 'moody' when it doesn't always get what it wants. 
The latter metaphor above is in our view particularly revealing, because it can be interpreted to include both a superiority-inferiority setting (the reference to 'teenager') and the description of Them making demands 'in a way that doesn't always have a match in reality'.

Animal-related metaphors of Merita by Nordbanken managers include 'Finnish lion,' 'tiger with tail raised high', 'well-built tiger' and 'wolf'. In contrast to the 'harmless' or 'soft' metaphors by Nordbanken people on Merita, all of these can be interpreted to be 'dangerous' and/or 'aggressive'. Merita was also described as 'giant' and 'colossus'. However, these may also simply referring to the bank's dominant market share in Finland.

\section{Modernity}

Most cultural comparisons also involve images of 'modernity,' which are closely linked with questions of power (e.g. Westwood, 2001). Related to the previous themes, our material reflects various kinds of self-evaluations ranging from self-criticism to the glorifiction of one's organization. Similarly, it includes positive evaluations of the partner as well as tendencies to promote oneself at the expense of the other. However, the metaphors also point to a post-colonial 'Big Brother-Little Brother' relationship in which Swedes tend to be categorized as more and Finns respectively less'mature'. 6

A colonizing attitude is not so apparent with the self-descriptions of the Swedes which often seemed to associate Nordbanken with archetypal Swedishness (e.g. 'Svensson' - an archetypal Swede). Association of 'self' and 'normality' is, however, a typical characteristic in the construction of 'colonizing' positions (e.g. Prasad, 1997; Saïd, 1979). In contrast, specific metaphors on Merita produced by the Nordbanken people reflected a clearly patronizing attitude:

Junior.

Eastern European street kiosk shall symbolize my ignorance of Merita's range of products and structure ... the selection is hidden behind overstocked windows.

As to the Merita managers, it was specifically through metaphors of Them that they constructed dominance in the relationship:

Father. 
Playing a game where one listens to the other with the manners of a master.

Little big brother that monitors.

The 'little big brother' metaphor is particularly interesting as it focuses on the disparity between the considerable domestic market share of Merita and the inferiority felt in relation to the Swedes in MeritaNordbanken. These examples can be seen as interesting evidence of self-constructed inferiority positions, which tend to characterize post-colonial settings (e.g. Prasad, 1997; Saïd, 1979). They also hint at a specific surrender to the Swedish power position in this particular merger, for example, in the choice of corporate language.

However, the Finnish self-images could also reflect an inferiority position (e.g. 'big child'). Perhaps there is a link here to what has been termed the Finnish tradition of stigmatization (Apo, 1998); national identification involves an element of suffering. A touch of regret is evident in the following metaphor on Us by a Merita manager:

First class restaurant turning into a fastfood joint.

Of the many interesting Finnish self-descriptions involving a defensive attitude towards the other side, the 'Asterix's Gaulish village' metaphor is particularly revealing. Those who are familiar with the cartoons by Uderzo and Goscinny may agree that Asterix's little village is itself originally a metaphor for local (Gaulish $\rightarrow$ French) traditions and ways of life against (Roman $\rightarrow$ American) imperialism and colonization. In Asterix cartoons, the villagers are undisciplined and quarrelsome, but when the colonizers time after time try to invade their territory, the villagers unite and repel the mighty opponents. Here Nordbanken - or Swedes can be seen as colonizers.

\section{Construction of images of Common Future}

Constructing a common future identity can be seen as another key identitybuilding process in the merger context. Ideally, it can represent 'frame restructuring,' which helps people to reconcile the problematic differences and move forward (e.g. Schön, 1979; Yanow, 1992). Although the metaphors for the new organization were sought for this particular purpose, it should be noted that images constructed of Us and Them can also be interpreted through a need for new identity. For example, both Nordbanken and Merita were described as 'ships'; 'on the way' and/or seeking a new direction. 
'Family' and 'house' are typical examples of metaphors that clearly represent an attempt to break free of the internal organizational and national division and juxtaposition. Similarly, references to 'Mercedes' or other icons of 'excellence' serve such purpose. At times, the metaphors by Nordbanken and Merita managers were explicit attempts to (re)construct the underlying differences into strengths. Nordbanken managers, for example, described the new organization as 'decathlon champion' and 'game where two good teams of different origins join forces. . . A Merita employee came up with the metaphor of 'effective professional team'. A Nordbanken manager described the future as follows:

Recent graduate, a competent 25-year-old, who with great enthusiasm and drive has decided to change the world by, in a constructive way, making good use of everyone's potential regardless of age, gender and nationality.

The so called 'chain metaphors' were particularly interesting attempts to expressly move from a previous state to another. A Merita manager produced an explicit narrative from past to present with an apparent intention to build a new positive Common Future:

Nordbanken: Female farmer, a single parent, who tries to farm by EU rules. Supports equality and green values.

Merita: Male, middle-aged engineer, married twice, with a certain amount of international experience. Has lost his favorite child.

MeritaNordbanken: The engineer and the farmer get married after two years of living under the same roof. The EU cucumbers grow as never before, and the engineer becomes rich from his financial engineering invention. Soon, they get two wellformed children.

The Nordbanken manager who described Us as 'athlete running the 5000 metres . . ' and Them as 'sprinter' portrayed the Common Future in MeritaNordbanken as follows:

Athlete running the 800 meters, who for the most part, with a fast,steady tempo, runs the entire race with a pre-set tactic.

In another example, a Norbanken manager described the future as a move from internal fights to an exploitation of this experience: 'battlefield now,elite force in the future'. 
The metaphors of Common Future often implied reference to the particular origins and special characteristics of the envisaged new organization. For example, a representative of Merita drew upon (as such problematic) eastern and western origins:

House with a touch of eastern exotique (the Finnish Attila spirit) and western prosperity (Swedish refinement and discussion).

Most significantly, the Nordbanken (i.e. Swedish) representatives built new

images out of what can be termed a common Nordic origin:

Nordic house. .

Nordic department store.

Nordic Viking ship.

These were particularly important metaphors because the whole organization was later named Nordea and the group started an image-building campaign drawing on this pan-Nordic imagery. Interestingly, not a single reference to Nordic origins could be found in our Finnish metaphor material on the Common Future in MeritaNordbanken. One is tempted to argue here that both Swedes and Finns easily associate 'Nordic' (or 'Scandinavian') with Swedishness, the ideal norm, and that this image is thus problematic. As an example of this, two Nordbanken managers came up with curious metaphors on Common Future, with reference to 'Nordic' origins:

The great power period7 in peace time.Conqueror (in crusade over the Nordic and Baltic states). The first metaphor is a direct reference to the period in history when the Kingdom of Sweden was at its largest, controlling not only Finland but a major part of the Baltic states and some regions in Poland. The second one is similar, with an explicit emphasis on 'conquering'. These metaphors thus clearly reconstruct a post-colonial future.

Many constructions of the Merita people, in turn, reflected a more open division and confrontation within the organization:

Challenge.

Jungle of corporate cultures. 
Eagle with two heads.

Tower of Babel.

Similarly, with a more nationalistic tone, Merita managers produced the following metaphors:

House made of stone (Ericsson if one affects the market wrong, Nokia if one makes the right decisions and listens to the customer). ${ }^{8}$

International match.

National competition.

One could also read a fear of Swedish dominance in the metaphors of the Finns such as:

Polar bear.

Arlanda.

Although 'polar bear' refers to a Northern image of the bank, it also reflects the power of the Swedes because it is the official symbol of Nordbanken.Arlanda is the international airport outside Stockholm, and thus also hints at Swedish dominance in the new post-merger organization.

\section{Revealing cognitive, emotional and political aspects of metaphoric cultural identity- building processes}

The main point of our analysis is that looking at the metaphoric constructions reveals subconscious or unarticulated cognitions and emotions with various power implications. We can thus see how the conscious or subconscious imageries, including all kinds of myths and legends, are connected with the specific identity-building processes characterizing the merger context. This view consequently emphasizes the complexity and ambiguity of social identitybuilding processes, which are too often conceptualized in overly simplistic ways.

What is most important for understanding the cultural identity-building processes, the metaphoric perspective reveals the holistic nature of these constructed identities. More traditional approaches in particular tend to focus on the cognitive aspects of these processes, 
whereas the metaphor perspective also allows one to see the emotional and political elements. As to the cognitive side, our analysis illustrates how the metaphors of Us and Them may reflect and even create increasing cultural awareness and understanding. In fact, many of the metaphors seem to be able to coin key cultural characteristics in particularly illuminative ways. In this analysis, we have not given emphasis to different tropes, but it seems to us that some of the most brilliant metaphors actually involved irony that could help in making apparent some key cultural understandings without falling into the trap of self-evident images (see Manning, 1979; Oswick et al., 2002).

However, at the same time, the metaphors also seem to invoke and reproduce cultural stereotypes. These stereotypes, at worst, actually appear to reinforce belief in 'fundamental cultural differences,' which is obviously a very problematic notion in merger contexts calling for attempts to create new organizational culture and promote social cohesion. In the international context, as is evident in our material, the metaphors of Us and Them seem to be vehicles for the nationalist ideology. Indeed, it seems to be the case that such cultural identity-building occasions are events that recreate nations 'as imagined communities' (Anderson, 1983) and the associated prototypes and stereotypes. This does involve rather simplistic framings, resembling what Billig (1995) has called 'banal nationalism'.

The metaphors created for the new Common Future at best represented 'a break' with previous conceptions and 'frame reconstruction' (e.g. Gherardi, 2000; Schön, 1979; Yanow, 1992). As well illustrated by the construction of chain metaphors (e.g. 'the female farmer,' etc.), the metaphors were at times conscious cognitive efforts to move from one cultural frame to another. One should not, however, forget that many of the metaphors constructed for the common future actually represented and even recreated the image of internal confrontation. In many cases, they could be seen as intermediary stages focusing attention on internal juxtaposition and confrontation before the next ideal state of integration and cohesion. However, even many of the metaphors apparently intended as positive images for the common future involved problematic connotations. In fact, even the very interesting 'Nordic' images could involve a reconstruction of Swedish colonization from the Finnish perspective.

As to the emotional aspects of the metaphor constructions, it is evident that the force of the metaphors is related to their affective responses (e.g. Gherardi, 2000). In brief, metaphors such as those in our material should be understood as cognitive-emotional hybrids able to make visible the complexity of cultural identities. The emotional in our material is probably 
most clearly visible in metaphors that were linked with openly nationalist framings. Especially on the Finnish side, many of the metaphors opened up highly traumatic experiences of Finnish-Swedish relationships. As our analysis above clearly illustrates, this relationship still appears to resemble a post-colonial setting in which the emotional is very strongly present. In fact, the emotional richness of the nationalist imageries is thought provoking given the fact that the people involved in the metaphor exercise represented top management, not the 'employees' or the 'media'. Although often portrayed as such, top management is clearly not free from the emotional and even banal nationalism in the merger context.

The metaphor perspective also gives us insights into the political aspects of cultural identitybuilding processes. On the one hand, the metaphors themselves involve (re)construction of organizational power relationships. The most obvious power effects in our material are related to the constructed superiority-inferiority relationships. In this setting, the Swedes were frequently portrayed as the Big Brother, whereas the Finns carried the image of the Little Brother, with all kinds of perceptive and attitudinal implications. What is noteworthy in our material is that the inferior position was often constructed by the Finns themselves. Although not surprising for some postcolonial analysts (Banerjee \& Linstead, 2001; Prasad, 1997; Saïd, 1979), this finding is, however, relatively new in the context of cultural identitybuilding. It shows how precisely the images of the past tend to have power over people coping with contemporary organizational challenges.

On the other hand, the ability to influence metaphor construction involves second-order organizational power. Although organizational cultures and identity constructions are not easily controllable by any specific agency, there are specific settings such as this cultural seminar series and particular programs such as corporate identity-building that can strongly influence the dominant organizational images (albeit not all the meanings associated). It is, for example, very clear that this kind of specific exercise unavoidably brings up cultural differences and the need to construct a new common future. This is likely to be in the interests of some (such as those wishing to promote 'cultural' issues in the organization and aiming at highlighting some problematic questions), but probably not all (such as those wishing to silence such issues as obstacles to speedy integration). In this case, the corporate identity-building subsequently focused on the Nordic image of the group. This may work as frame restructuring, but it also promotes the view of a more integrated rather than less 
integrated organization in which country organizations have a less powerful role than before (compare the names 'MeritaNordbanken' and 'Nordea'). As shown in our analysis, some of the connotations to the 'Nordic heritage' may also be linked with the historical past when Sweden colonized Finland and other Nordic countries.

It should be emphasized that although the images created in cultural identity-building processes are revealing, they are also concealing. Thus, while picking up new contextspecific ways of portraying oneself and the others, people also exclude other, potentially equally important, aspects. Depending on the circumstances and the issues at hand, the managers of our case may see themselves more as Finns/Swedes, representatives of the headquarters/ members of the country organizations, managers in charge of changes/subjects of changes, protagonist/antagonists of specific issues, innovators/ guardians of specific traditions, promoters of tight/loose integration, managerial generalists/representatives of specific banking professions, men/women, than anything else. The metaphor perspective thus makes it easy to understand why we often confront partial, fragmented, ambiguous and contradictory images instead of coherent and stable organization-wide identity constructions in changing organizations (see also Gioia et al., 2000). In particular, we can better comprehend why overly simplistic cultural models, whether they concentrate on organizational and national cultural differences or organization-wide responses to change, are rarely able to describe the complexity of post-merger organizational 'reality,' to say nothing of serving as unproblematic management tools.

\section{Conclusion}

In this article, we have examined post-merger cultural identity-building processes from a metaphoric perspective. We have focused on two central identity-building processes: construction of difference and construction of common future identity. We maintain that these identity-building processes are crucial for understanding how the people involved respond cognitively and emotionally to the planned and anticipated 'changes'. This, in turn, helps us to understand emerging forces within the organizations; forces which on the surface appear as enthusiasm, commitment, non-compliance or resistance.

We have, in particular, claimed that the metaphoric perspective allows us to reveal the subconscious and unarticulated imageries involved in identity-building. We have also argued 
that this allows us to take a closer look at various cognitive, emotional and political processes at work. By so doing, we have provided a challenge for the most simplistic acculturation and cultural management models that tend to dominate research on organizational change in general and mergers and acquisitions in particular.

The particular findings of our metaphor analysis are obviously case and context-specific. The metaphors produced and the meanings attached ultimately make sense only when the specific organizational histories, the historical post-colonial relationship between Finns and Swedes, and the particular dynamics of the merger are taken into account. Yet we want to emphasize that the basic dynamics of the cultural identity-building processes are likely to be analogous also in other settings. We can thus expect to see similar types of stereotypes in any merger or acquisition crossing national borders. It is also likely that most mergers and acquisitions dealing with dramatic changes will trigger strong emotional responses, which in international settings are easily linked with banal nationalism. We can also expect to see various types of superiority-inferiority constructions in cross-border settings. Think, for example, about the underlying historical heritage in German-Dutch, British-Irish, Swedish-Norwegian or Finnish-Estonian mergers.

While we have argued for the context-specificity cultural identities, we claim that our study has also relevance for research on organizational and national identities in general. By bringing in metaphors, we have provided one alternative view of looking at identity construction. Like some other scholars (Gioia et al., 2000), we have questioned the stability and coherence of organizational identities and the validity of overly simplistic identity models. Indeed, it seems to us that it is wothwhile to further develop the metaphoric perspective on organizational identity-building in future research. We also think that this article serves as an example of the strength of national identity images and nationalist ideology in multinational settings. In our view, research on nationalism should be given more attention in the context of organizational identity-building.

As our analysis shows, metaphors are particularly useful devices to bring in such cognitions and emotions that otherwise could be very difficult to 'capture'. Thus our analysis can be seen as a further encouragement to gather and analyze metaphor material for different purposes in organizational research. Like other studies on metaphors, this analysis, however, also shows that metaphors are particularly challenging ethnographic material for organizational researchers. The challenge lies in dealing with their ambiguity, fluidity and 
elusiveness. In our view, this challenge can be dealt with only if the ideas of contextuality and intertextuality are taken seriously. As illustrated by our analysis, in most cases, this probably implies a need for rich ethnographic data around the organization and the specific phenomena in question.

This study has been exploratory and inductive in nature. Future studies could focus on more specific themes in the context cultural identity-building. First, future studies could analyze the use and interrelationships of different tropes. Synecdoche, metonymy, irony and other tropes besides metaphor (proper) deserve specific attention as 'identity-building mechanisms' (e.g. Oswick et al., 2002). Second, our analysis points to the identity-building processes of the 'inferior' (demonstrated in our case by the Finns in Merita) as an interesting area for further research. The question of how and why the 'oppressed' (re)construct their inferiority, while legitimating their national identity, needs to be examined more closely. Third, the gendered nature of identity-building also provides an interesting and important avenue for future research. In fact, many, if not most, of the metaphors of our analysis seem to be gendered in nature.

In conclusion, metaphors are 'messy' constructs because of the constant possibility for reinterpretation. As our analysis has shown, they are thus controversial tools for use in intentional organizational identity-building and 'slippery' objects for empirical analysis. Yet this 'messiness' is also a good metaphor for the purposes of examining cultural identitybuilding processes. These processes involving various cognitive, emotional and political aspects are also messy, whether we like it or not.

\section{Notes}

1. There are many definitions of metaphors that provide different types of distinctions between metaphors and other tropes (e.g. Miller, 1982). Lately, people have particularly criticized the tendency to view 'metaphors' (proper) as 'master tropes' (Oswick et al., 2002). For the purposes of this article, we stick to the inclusive definition of 'metaphor,' including various types of tropes that can work as metaphoric expressions (see Miller, 1982). 
2. Not all of the participants delivered the pre-assignment. Later, those expressions of the participants that were not seen as 'metaphoric' (e.g. direct descriptions of the banks) were excluded.

3. The Kingdom of Sweden has not fought a war since the early nineteenth century.

4. One of the Nordbanken employees described Us as 'infantry/staff battalion' and Them as 'tank battalion'.

5. There were four references to 'ant hill' in self-descriptions of Merita employees, one to denote Nordbanken and one MeritaNordbanken. There were none in the Nordbanken employees' self-descriptions, but two to denote Merita.

6. Finland used to be part of Sweden for almost 800 years. There is still a Swedishspeaking minority in Finland that is often associated with a 'privileged' position.

7. 'Stormaktstiden' in Swedish.

8. Ericsson is a global telecommunications company with Swedish roots. The Finnish media have been active in pointing out the contrast between Ericsson and Nokia in mobile telecommunications. Ericsson's financial performance has constantly lagged behind the performance of its counterpart with Finnish roots.

\section{References}

Aaltonen, M. Suomalaisen johtamisen arvojen ja alkukuvien jäljillä?: Myytit ja konnotaatiot lukiolaisten johtamiskäsityksissä. Turku, Finland: Turku School of Economics and Business Administration Doctoral Dissertation, Series A1, 1997.

Alvesson, M. The play with metaphors. In J. Hassard \& M. Parker (Eds), Postmodernism and organization. London: Sage, 1993, pp. 114-31.

Anderson, B. Imagined communities: Reflections on the origin and spread of nationalism. London: Verso Editions and NLB, 1983. 
Apo, S. Suomalaisen stigmatisoinnin traditio. In P. Alasuutari \& P. Ruuska (Eds), Elävänä Euroopassa. Tampere, Finland: Vastapaino, 1998, pp. 83-128.

Ashforth, B.E. \& Mael, F.A. Social identity and the organization. Academy of Management Review, 1989, 14(1), 20-39.

Banerjee, S.B. \& Linstead, S. Globalization, multiculturalism and other fictions: Colonialism for the new millennium? Organization, 2001, 8(4), 683-722.

Billig, M. Banal nationalism. London: Sage, 1995. Black, M. Models and metaphors: Studies in language and philosophy. Ithaca, NY: Cornell University Press, 1962.

Booth, W.C. Metaphor as rhetoric: The problem of evaluation. In S. Sacks (Ed.), On metaphor. Chicago: The University of Chicago Press, 1978, pp. 47-70.

Bosman, J.P. Persuasive effects of political metaphors. Metaphor and symbolic activity, 1987, $2,97-113$.

Breakwell, G.M. \& Lyons, E. Changing European identities: Social psychological analyses of social change. Oxford: Butterworth-Heinemann, 1996.

Cazal, D. \& Inns, D. Metaphor, language and meaning. In D. Grant, T. Keenoy \& C. Oswick (Eds), Discourse and organizations. London: Sage, 1998, pp. 258-78.

Deetz, S.A. Metaphors and the discursive production and reproduction of organizations. In L. Thayer (Ed.), Organization-communication: Emerging perspectives. Norwood, NJ: Ablex, 1986, pp. $168-82$.

Ekwall, A. \& Karlsson, S. Kohtaaminen Suomi-Ruotsi - kirja kulttuurieroista ja johtajuudesta. Vaasa, Finland: Storkamp Media, 1999.

Elsass, P.M. \& Veiga, J.F. Acculturation in acquired organizations: A force-field perspective. Human Relations, 1994, 47, 431-53.

Fernandez, J.W. Beyond metaphor: The Theory of tropes in anthropology. Stanford, CA: Stanford University Press, 1991. 
Gertsen, M.C., Søderberg, A.-M. \& Torp, J.E. Different approaches to understanding of culture in mergers and acquisitions. In M.C. Gertsen, A.-M. Søderberg \& J.E. Torp (Eds), Cultural dimensions of international mergers and acquisitions. Berlin: de Gruyter, 1998.

Gherardi, S. Where learning is: Metaphors and situated learning in a planning group. Human Relations, 2000, 53, 1057-80.

Gioia, D., Schultz, M. \& Corley, K.G. Organizational identity, image, and adaptive instability. Academy of Management Review, 2000, 25(1), 63-81.

Grant, D. \& Oswick, C. (Eds). Organization and metaphor. London: Sage, 1996.

Hirsch, P.M. From ambushes to golden parachutes: Corporate takeovers as an instance of cultural framing and institutional integration. American Journal of Sociology, 1986, 91, 80037.

Hirsch, P.M. \& Andrews, J.A. Ambushes, shootouts, and the knights of the round table: The language of corporate takeovers. In L. Pondy, P. Frost, G. Morgan \& T. Dandrige (Eds), Organizational symbolism. Greenwich, CT: JAI Press, 1983, pp. 145-56.

Hogg, M.A. \& Terry, D.J. Social identity and self-categorization processes in organizational contexts. Academy of Management Review, 2000, 25(1), 121-40.

Laine-Sveiby, K. Svenshet som strategi. Stockholm: Timbro, 1987. 448 Human Relations $56(4)$

Laine-Sveiby, K. Suomalaisuus strategiana. Porvoo, Finland: WSOY, 1991.

Lakoff, G. \& Johnson, M. Metaphors we live by. Chicago: University of Chicago Press, 1980. Laurila, J. Management in Finland. In M. Warner \& P. Joynt (Eds), Management in Europe. London: Thomson Learning Business Press, 1999.

Lewis, R. When cultures collide: Managing successfully across cultures. London: Brealey, 1996.

Löfgren, O. Materializing the nation in Sweden and America. Ethnos, 1993, 59(3-4), 161-93. 
Manning, P.K. Metaphors of the field: Varieties of organizational discourse. Administrative Science Quarterly, 1979, 24, 660-71.

Marshak, R.J. Managing the metaphors of change. Organizational Dynamics, 1993, 22(1), $44-56$.

Miles, M.A. \& Huberman, M.A. Qualitative data analysis: An expanded sourcebook. Thousand Oaks, CA: Sage, 1994.

Miller, D.F. Metaphor, thinking and thought. Et Cetera, 1982, 39(2), 134-50.

Miller, D.F. Social policy: An exercise in metaphor. Knowledge, 1985, 7(2), 191-215.

Morgan, G.A. Images of organizations. London: Sage, 1986.

Morgan, G.A. Imaginization. Newbury Park, CA: Sage, 1993.

Nahavandi, A. \& Malekzadeh, A.R. Acculturation in mergers and acquisitions. Academy of Management Review, 1988, 13, 79-90.

Olie, R. Shades of culture and institutions in international mergers. Organization Studies, $1994,15,381-405$.

Ortony, A. Why metaphors are necessary and not just nice. Educational Theory, 1975, 25(1), $45-53$.

Ortony, A. (Ed.). Metaphor and thought. Cambridge: Cambridge University Press, 1979.

Oswick, C. \& Grant, D. (Eds). Organization development: Metaphorical explorations. London: Pitman, 1996.

Oswick, C., Keenoy, T.W. \& Grant, D. Note: Metaphor and analogical reasoning in organization theory: Beyond orthodoxy. Academy of Management Review, 2002, 27, 294303.

Oswick, C. \& Montgomery, J. Images of an organization: The use of metaphor in a multinational company. Journal of Organizational Change Management, 1999, 12(6), 501-23. 
Prasad, A. The colonizing consciousness and representations of the other. In P. Prasad, A.J. Mills, M. Elmes \& A. Prasad (Eds), Managing the organizational melting pot. Thousand Oaks, CA: Sage, 1997, pp. 285-311.

Putnam, L., Phillips, N. \& Chapman, P. Metaphors of communication and organization. In S. Clegg, C. Hardy \& W. Nord (Eds), Handbook of organization studies. London:Sage, 1996, pp. 375-408.

Quinn, N. The cultural basis of metaphor. In J.W. Fernandez (Ed.), Beyond metaphor: The theory of tropes in anthropology. Stanford, CA: Stanford University Press, 1991, pp. 56-93.

Richards, I.A. The philosophy of rhetoric. London: Oxford University Press, 1936.

Sackman, S. The role of metaphors in organization transformation. Human Relations, 1989, 42(6), 463-85.

Sacks, S. On metaphor. Chicago: The University of Chicago Press, 1978.

Saïd, E.W. Orientalism. New York: Vintage, 1979.

Schneider, S.C. \& Dunbar, R.L.M. A psychoanalytic reading of hostile takeover events. Academy of Management Review, 1992, 17, 537-67.

Schön, D.A. Generative metaphor: A perspective on problem-setting in social policy. In A. Ortony (Ed.), Metaphor and thought. Cambridge: Cambridge University Press, 1979, pp. 137-63.

Vaara et al. The international match 449 Tajfel, H. Social identity and intergroup relations. Cambridge: Cambridge University Press, 1982.

Tajfel, H. \& Turner, J.C. An integrative theory of intergroup conflict. In W.G. Austin \& S. Worchel (Eds), The social psychology of intergroup relations. Monterey, CA: Brooks/Cole, 1979, pp. 33-47.

Tsoukas, H. The missing link: A transformational view of metaphors in organizational science. Acadmy of Management Review, 1991, 16(3), 566-85. 
Turner, J.C. Social categorization and the self-concept: A social cognitive theory of group behaviour. In E.J. Lawler (Ed.), Advances in group processes: Theory and research, 2. Greenwich, CT: JAI Press, 1985, pp. 77-121.

Vaara, E. Cultural differences and postmerger problems: Misconceptions and cognitive simplifications. Nordiske Organisasjonsstudier [Nordic Organization Studies], 1999, 1, 59-88.

Very, P., Lubatkin, M., Calori, M. \& Veiga, J. Relative standing and the performance of recently acquired European firms. Strategic Management Journal, 1997, 18, 593-614.

Weick, K. Sensemaking in organizations. Thousand Oaks, CA: Sage, 1995.

Westwood, R. Appropriating the other in the discourse of comparative management. In R. Westwood \& S. Linstead (Eds), The language of organization. London: Sage, 2001.

Wilson, F. Language, technology, gender and power. Human Relations, 1992, 45(9), 883904.

Yanow, D. Supermarkets and culture clash: The epistemological role of metaphors in administrative practice. American Review of Public Administration, 1992, 22(2), 89-109.

Yanow, D. Conducting interpretive policy analysis. Qualitative research methods series, 47. Thousand Oaks, CA: Sage, 2000.

Zander, L. Management in Sweden. In M. Warner \& P. Joynt (Eds), Management in Europe. London: Thomson Learning Business Press, 1999. 450 Human Relations 56(4)

Eero Vaara has been working as a Professor at the Department of International Business at the Helsinki School of Economics since 1999. He is currently a visiting professor at Ecole Management de Lyon. His current work focuses on discursive perspectives on organizational change, industrial restructuring and globalization. His research interests also include philosophical and methodological issues in management and organization research. He has published in leading international journals such as Organization Studies, Journal of Management Studies, Organization, British Journal of Management, Scandinavian Journal of Management and Nordic Organization Studies. [E-mail: evaara@hkkk.fi] 
Janne Tienari is Professor of Management and Organizations at Lappeenranta University of Technology, Finland. His research interests include gender and organizing, media discourse, social construction of organizational change and the spread of management ideas. His research is focused in the fields of financial services, management consulting and business press. His work has recently been published in Organization Studies, Organization, British Journal of Management, Scandinavian Journal of Management and Gender, Work and Organization.

Risto Säntti is working as Senior Project Manager in Group HR Centre in Nordea Ab. He received his doctorate from University of Tampere focusing on cultural interaction in international mergers. His research interests focus on corporate cultures and management of organizational knowledge. 